\title{
Carcinoembryonic Antigen-Related Cell Adhesion Molecule 8
}

National Cancer Institute

\section{Source}

National Cancer Institute. Carcinoembryonic Antigen-Related Cell Adhesion Molecule 8. NCI Thesaurus. Code C118590.

Carcinoembryonic antigen-related cell adhesion molecule 8 (349 aa, $38 \mathrm{kDa}$ ) is encoded by the human CEACAM8 gene. This protein may play a role in the activation of immune cells. 